\title{
PERANCANGAN ARSITEKTUR SISTEM TIKET ELEKTRONIK KERETA API MENGGUNAKAN KERANGKA SERVICE ORIENTED ENTERPRISE ARCHITECTURE \\ (Studi Kasus : PT Railink)
}

\author{
Irpan Budiana, Irma Wibiyanti \\ Program Studi Teknik Informatika ST INTEN \\ Email : irpan.budiana@gmail.com,irma26wibiyanti@gmail.com
}

\begin{abstract}
ABSTRAK
Penelitian bertujuan untuk memberikan guideline perancangan arsitektur enterprise sistem e-ticketing kereta api di Indonesia berorientasi service dengan menggunakan kerangka Service Oriented Enterprise Architecture (SOEA). Metodologi analis dan desain berorientasi objek $(O O A D)$ digunakan dalam menggambarkan struktur perancangan sistem e-ticketing kereta api. Sedangkan kerangka perancangan arsitektur enterprise e-ticketing kereta api berorientasi service terdiri dari analisis arsitektur as-is yang menganalisis arsitektur yang sedang berjalan, dilanjutkan dengan perancangan arsitektur to-be untuk merancang arsitektur yang akan dikembangkan baik dari segi proses bisnis, aplikasi, dan infrastruktur. Perancangan arsitektur enterprise e-ticketing kereta api berbasis service juga menggunakan pola aristektur berbasis microservice dalam rangka memenuhi kebutuhan sistem yang resilient, scalable, interoperable, dan mampu diintegrasikan dengan berbagai standar platform.
\end{abstract}

Kata Kunci : Perancangan, arsitektur enterprise, e-ticketing, service oriented enterprise architecture, service oriented architecture, microservice, object-oriented analysis and design

\section{PENDAHULUAN}

PT Railink sebagai sebuah perusahaan swasta yang merupakan anak perusahaan dari PT Kereta Api Indonesia (Persero) dengan PT Angkasa Pura II (Persero) bertindak selaku operator dari Kereta Api (KA) Bandara. Dalam mengoperasikan KA Bandara dan menunjang bisnis usaha terutama dalam angkutan penumpang, PT Railink melakukan bisnis penjualan tiket yang diterapkan di stasiun-stasiun pemberangkatan maupun channel-channel pemesanan dan pembayaran tiket secara elektronik melalui $e$ ticketing. Dalam implementasi sistem e-ticketing tersebut dibutuhkan sebuah teknologi yang memungkinkan bentuk akhir dari sebuah program atau aplikasi komputer berupa sebuah service atau fungsi yang melakukan sebuah tugas atau proses spesifik yang dikenal dengan istilah web service. Dimana dengan adanya teknologi web service, memungkinkan perpaduan fungsi-fungsi dalam membangun sebuah program aplikasi 
tanpa bergantung lagi pada sistem operasi maupun bahasa pemrograman yang digunakan.

Modul-modul e-ticketing yang dibangun dan diintegrasikan diantaranya modul pemesanan, pembayaran (antar bank dan payment gateway), inventory tempat duduk, customer relationship management, voucher, dan lain-lain. Dengan adanya kebutuhan integrasi modul, sistem e-ticketing yang dibangun memerlukan ketersediaan yang tinggi (availability), dapat memenuhi aspek resiliensi supaya dapat beradaptasi serta bertahan terhadap perubahan maupun kesalahan maupun kerusakan infrastruktur serta memiliki kemampuan menyesuaikan kebutuhan baru yang belum eksplisit tersedia sebelumnya (scalability).

Sehingga untuk pengembangan perangkat lunak sistem e-ticketing memerlukan sistem yang mendukung integrasi bisnis berbagai layanan (service) dari berbagai sumber informasi dan transaksi, interoperabilitas antar layanan, ketersediaan tinggi, memiliki aspek resiliensi dan skalabilitas, serta mampu mengakomodasi adanya perubahan untuk kemudian dilakukan adaptasi terhadap perubahan tersebut dengan cepat dan tepat, maka diperlukan sebuah pattern arsitektur pengembangan perangkat lunak yang mampu mengakomodasi kebutuhan dan faktor kualitas dari perangkat lunak tersebut dengan arsitektur sistem berbasis service (service-oriented). Arsitektur ini lebih dikenal dengan nama microservice.

\section{LANDASAN TEORI}

\subsection{Arsitektur Enterprise}

Arsitektur enterprise merupakan pendekatan logis, komprehensif, dan holistik untuk merancang dan meng-implementasikan sistem dan komponen sistem yang bersama (Parizeau, 2002). Arsitektur Enterprise merupakan Blueprint pemetaan hubungan antar komponen dan semua orang yang bekerja di dalam perusahaan secara konsisten untuk meningkatkan kerja sama/kolaborasi, serta koordinasi diantaranya (Ward, John and Peppard, Joe, 2002). Arsitektur Enterprise adalah deskripsi dari misi stakeholder yang di dalamnya termasuk informasi, fungsionalitas/kegunaan, lokasi organisasi dan parameter kinerja. EA mengambarkan rencana untuk mengembangkan sebuah sistem atau sekumpulan sistem (Osvalds, 2001). 


\subsection{Service Oriented Architecture (SOA)}

Service Oriented Architecture (SOA) adalah bagian utama dari service computing platform yang membawa konsep, teknologi, dan tantangan baru. da tiga hal penting yang menjadikan sebuah infrastruktur dapat disebut sebagai service oriented architecture, yaitu logika bisnis yang dienkapsulasi sebagai service, dan proses komunikasi antar service dengan menggunakan message. Dalam hal ini, service layer yang akan menjembatani hubungan antara business logic dan application logic (Erl, 2005). Service Oriented Architecture adalah sebuah kumpulan yang terdiri atas tools, teknologi, framework, dan best practice yang memudahkan implementasi sebuah service secara cepat. Proses dalam mengimplementasi SOA menggunakan metodologi yang mengidentifikasikan service yang dapat dipergunakan kembali (reusable) dalam aplikasi dan organisasi suatu perusahaan (Mittal, 2007)

\subsection{Arsitektur Microservice}

Microservice is an approach to developing a single application as a suite of small services, each running in its own process and communicating with lightweight mechanisms, often an HTTP resource API. These services are built around business capabilities and independently deployable by fully automated deployment machinery. There is a bare minimum of centralized management of these services, which may be written in different programming languages and use different data storage technologies. (Lewis and Fowler:2014)

Arsitektur microservice memecah aplikasi yang kompleks ke dalam serviceservice otonom yang kecil. Proses-proses independen saling berkomunikasi melalui berbagai bahasa Application Programming Interface (API) yang juga independen. Service-service tersebut saling terpisah dan fokus pada tugas atau pekerjaan yang kecil, sehingga hal tersebut menjadikannya sebagai sebuah pendekatan modular dalam membangun sebuah sistem. Service-service tersebut mudah diganti, dirancang untuk memenuhi kebutuhan bisnis yang spesifik, dan dapat diimplementasikan menggunakan teknologi yang berbeda-beda. Selain itu, karena microservice bersifat otonom, service tersebut dibangun dan didistribusikan menggunakan metodologi pengembangan software Continuous Delivery (CD). 


\section{Microservice dan SOA}

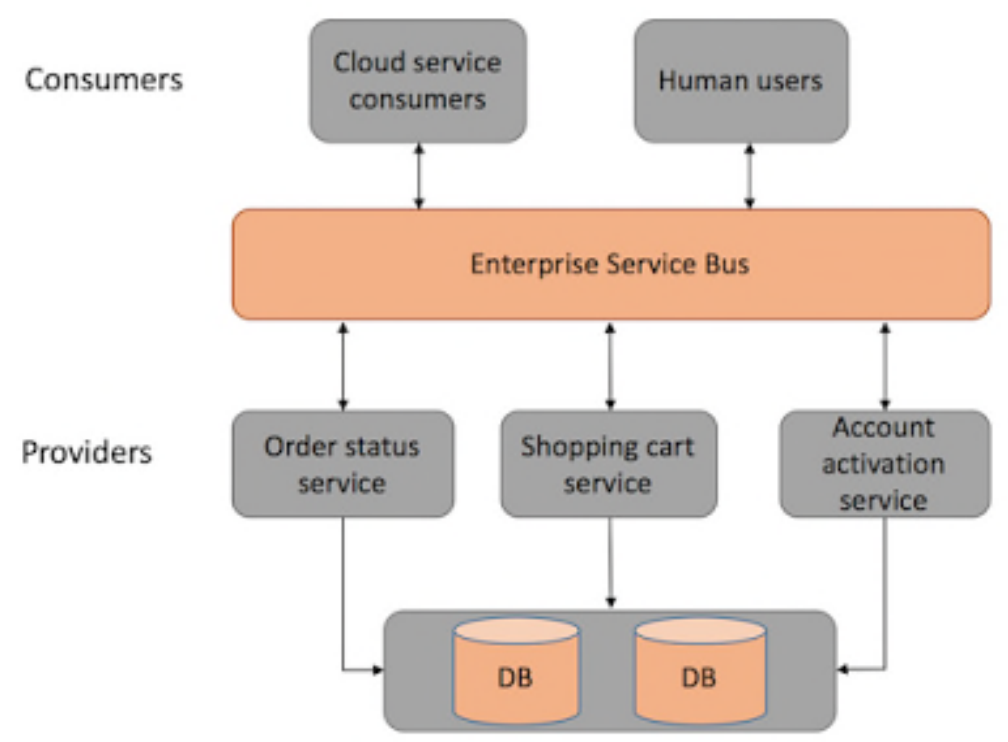

Gambar 1. Arsitektur SOA

Di dalam microservice, service-service dapat beroperasi dan didisribusikan secara independen dari service lainnya tidak seperti SOA, sehingga memudahkan dalam pendistribusian service versi baru serta perubahan spesifikasi service secara mandiri. Di dalam SOA, ESB menjadi sebuah titik tunggak kegagalan yang akan berdampak pada keseluruhan aplikasi dikarenakan semua service berkomunikasi melalui ESB, jika salah satu service lambat, dapat mengakibatkan ESB harus ditutup untuk request dari service tersebut. Dari hal inilah, microservice jauh lebih baik dalam hal fault tolerance. Sebagai contoh, jika terdapat sebuah kobocoran memori dalam sebuah microservice, maka hanya microservice itu saja yang terkena dampak. Microservice lainnya akan tetap lanjut menangani request-request. Di dalam SOA, service-service berbagi penyimpanan data (Gambar 2) sementara dalam microservice, setiap service dapat mempunyai penyimpanan data tersendiri. 


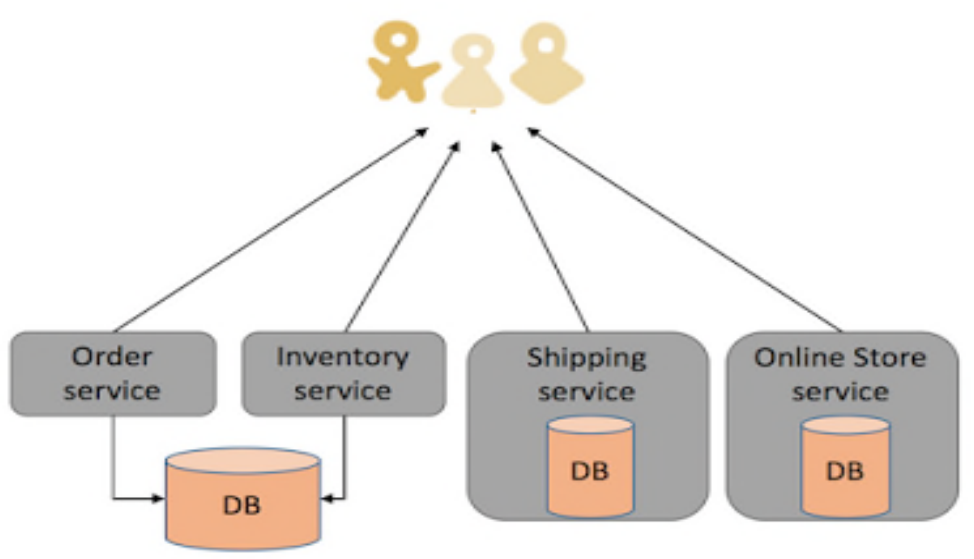

Gambar 2. Arsitektur Microservice

Baik SOA dan microservice, pengembangan harus mempertimbangkan kompleksitas arsitektur dan sistem terdistribusi. Pengembang harus mengimplementasikan mekanisme komunikasi antar-service di antara microservice atau di dalam ESB. Perbedaan utama antara SOA dan microservice terletak pada ukuran dan lingkupnya. Ukuran microservice secara signifikan lebih kecil dari pada kecenderungan ukuran SOA. Di sisi lain, sebuah SOA dapat berupa sebuah arsitektur monolitik atau dapat juga terdiri dari beberapa microservice.

\subsection{Kerangka Service Oriented Enterprise Architecture (SOEA)}

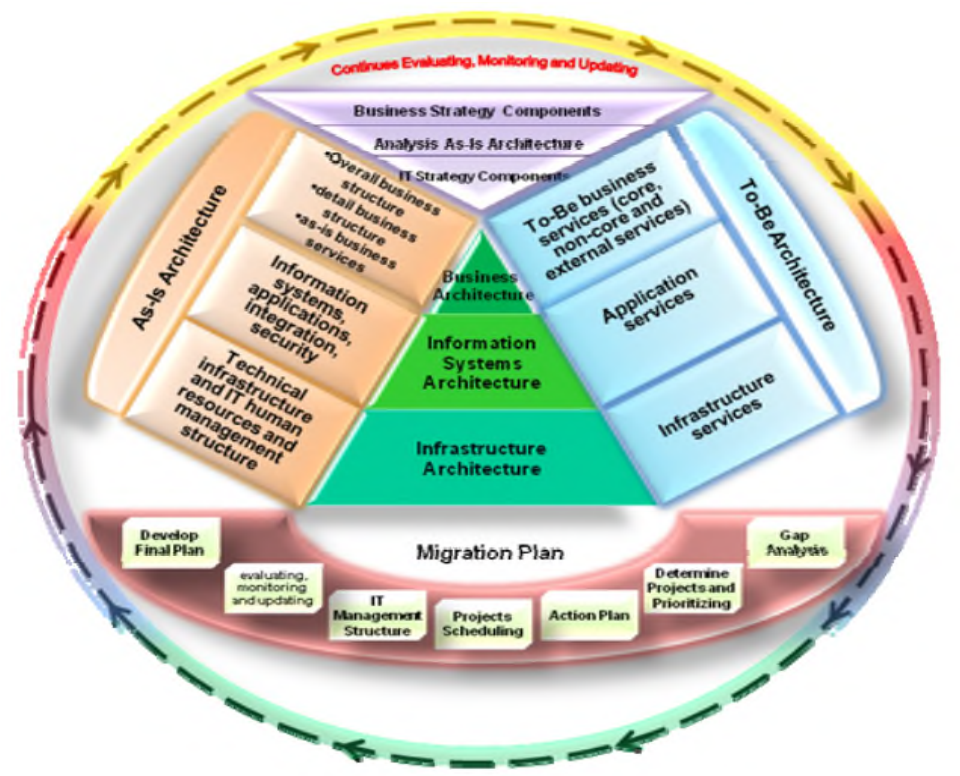

Gambar 3. Kerangka Service Oriented Enterprise Architecture (SOEA) 
Kombinasi EA dan SOA menghasilkan kerangka untuk mendokumentasikan aspek bisnis dan IT dengan mengutilisasi pendekatan berbasis service.

Akar framework SOEA berasal dari Federal Enterprise Architecture Framework (FEAF) dan Project Management Body of Knowledge (PMBOK). Layer arsitektur yang terdapat dalam SOEA adalah:

1. Layer Arsitektur

Dalam framework SOEA, terdapat tiga layer arsitektural:

a. Arsitektur Bisnis: Arsitektur Bisnis merupakan bagian penting dan layer pertama dalam SOEA yang mempengaruhi layer arsitektural lainnya. Di dalam layer ini, dikombinasikan pendekatan Business Process Management (BPM) dengan service orientation.

b. Aristektur Aplikasi : Di dalam arsitektur aplikasi didefinisikan suatu pendekatan komposit aplikasi yang mirip dengan Component Based Software (CBS) yang fokus pada pembangunan sistem software yang besar dengan mengintegrasikan komponen software yang sudah ada.

c. Arsitektur Infrastruktur

Setelah menentukan aplikasi komposit, di dalam layer infrastruktur, diidentifikasi lingkungan di mana service aplikasi mendukung semua service bisnis.

2. Fase Proyek

Tabel 1 menggambarkan fase, langkah, aktifitas, dan output yang diharapkan dari sebuah proyek SOEA. 
Tabel 1. Fase, Langkah, dan output aktivitas dari framework SOEA

\begin{tabular}{|c|c|c|c|}
\hline Phase & Step & Activity & Deliverable \\
\hline \multicolumn{2}{|c|}{ Phase 0: Project Planning } & $\begin{array}{l}\text { - Organizing the project } \\
\text { team } \\
\text { - Finalizing the scope of } \\
\text { the project } \\
\text { - Developing project } \\
\text { management plan }\end{array}$ & $\begin{array}{l}\text { - Project organizational } \\
\text { structure } \\
\text { - Scope statement } \\
\text { - Project Management } \\
\text { Plan (PMP) }\end{array}$ \\
\hline \multirow[t]{2}{*}{$\begin{array}{l}\text { Phase 1: } \\
\text { As-Is } \\
\text { Architecture }\end{array}$} & $\begin{array}{l}\text { Business As- } \\
\text { Is Architecture }\end{array}$ & $\begin{array}{l}\text { - Identifying the overall } \\
\text { business structure } \\
\text { - Extracting } \\
\text { organization's business } \\
\text { strategy components } \\
\text { - Identifying detail } \\
\text { business structure } \\
\text { - Extracting as-is business } \\
\text { services }\end{array}$ & $\begin{array}{l}\text { - Business conceptual } \\
\text { model } \\
\text { - IT and business strategy } \\
\text { components } \\
\text { - Business function } \\
\text { model, process model } \\
\text { and data model } \\
\text { - As-Is business services }\end{array}$ \\
\hline & $\begin{array}{l}\text { IT As-Is } \\
\text { Architecture }\end{array}$ & $\begin{array}{l}\text { Identifying technical IT } \\
\text { resources } \\
\text { - Identifying non- } \\
\text { technical IT resources }\end{array}$ & $\begin{array}{l}\text { - Information systems, } \\
\text { applications, integration, } \\
\text { security and } \\
\text { infrastructure } \\
\text { - IT human resources and } \\
\text { management structure }\end{array}$ \\
\hline \multicolumn{3}{|c|}{ Phase 2: Analysis of As-Is Architecture } & $\begin{array}{l}\text { - analysis of Business and } \\
\text { IT As-Is Architecture }\end{array}$ \\
\hline $\begin{array}{l}\text { Phase 3: } \\
\text { To-Be } \\
\text { Architecture }\end{array}$ & \multicolumn{2}{|c|}{ Business To-Be Architecture } & $\begin{array}{l}\text { To-Be business services } \\
\text { (core, non-core and } \\
\text { external services) } \\
\text { - Application services } \\
\text { - Infrastructure services }\end{array}$ \\
\hline Phase 4: Mi & ation Plan & $\begin{array}{l}\text { - Gap analysis } \\
\text { - Identifying projects and } \\
\text { prioritizing } \\
\text { - Developing evaluation } \\
\text { and updating plan } \\
\text { - Proposing IT } \\
\text { management structure }\end{array}$ & $\begin{array}{l}\text { - Gap analysis report } \\
\text { - Proposed projects } \\
\text { - Evaluation and updating } \\
\text { plan } \\
\text { - IT management structure }\end{array}$ \\
\hline
\end{tabular}

\subsection{Unified Modelling Language (UML)}

Unified modelling language (UML) merupakan seperangkat model kontruksi dan notasi yang dibentuk dalam pengembangan sistem berorientasi pada objek (Satzinger, 2012). Diagram-diagram bagian dari UML yang dapat dijelaskan sebagai berikut:

\subsubsection{Diagram Activity}

Diagram Activity merupakan diagram yang menunjukkan alur kerja atau aktivitas user secara berurutan.

\subsubsection{Diagram Use Case}

Diagram Use Case adalah diagram yang menunjukkan aktivitas yang dilakukan oleh sistem berupa respon terhadap permintaan pengguna serta hubungan antara aktor-aktor pengguna tersebut di dalam sistem. 


\section{$2.5 \quad$ E-ticketing}

Electronic Ticketing (e-ticketing) adalah sebuah dokumen elektronik yang banyak digunakan sebagai tiket penumpang moda transportasi. Di sisi lain menyebutkan $e$ ticketing merupakan suatu cara untuk mendokumentasikan proses penjualan dari aktifitas perjalanan pelanggan tanpa harus mengeluarkan dokumen secara fisik (Grace, 2009). Sehingga dapat diartikan bahwa e-ticketing merupakan sebuah teknologi yang berguna untuk menggantikan pengolahan dan penggunaan tiket tradisional (paper ticket) (Iwuagwu, 2006). Melihat dari sisi perkeretaapian, sistem e-ticketing berpeluang untuk meminimalkan biaya dan mengoptimalkan kenyamanan penumpang. E-ticketing mengurangi biaya proses tiket, menghilangkan formulir kertas dan meningkatkan fleksibilitas penumpang dan agen perjalanan. Tujuannya adalah untuk membuat pembelian atau pemesanan tiket lebih mudah (Karami, 2006).

\section{METODOLOGI}

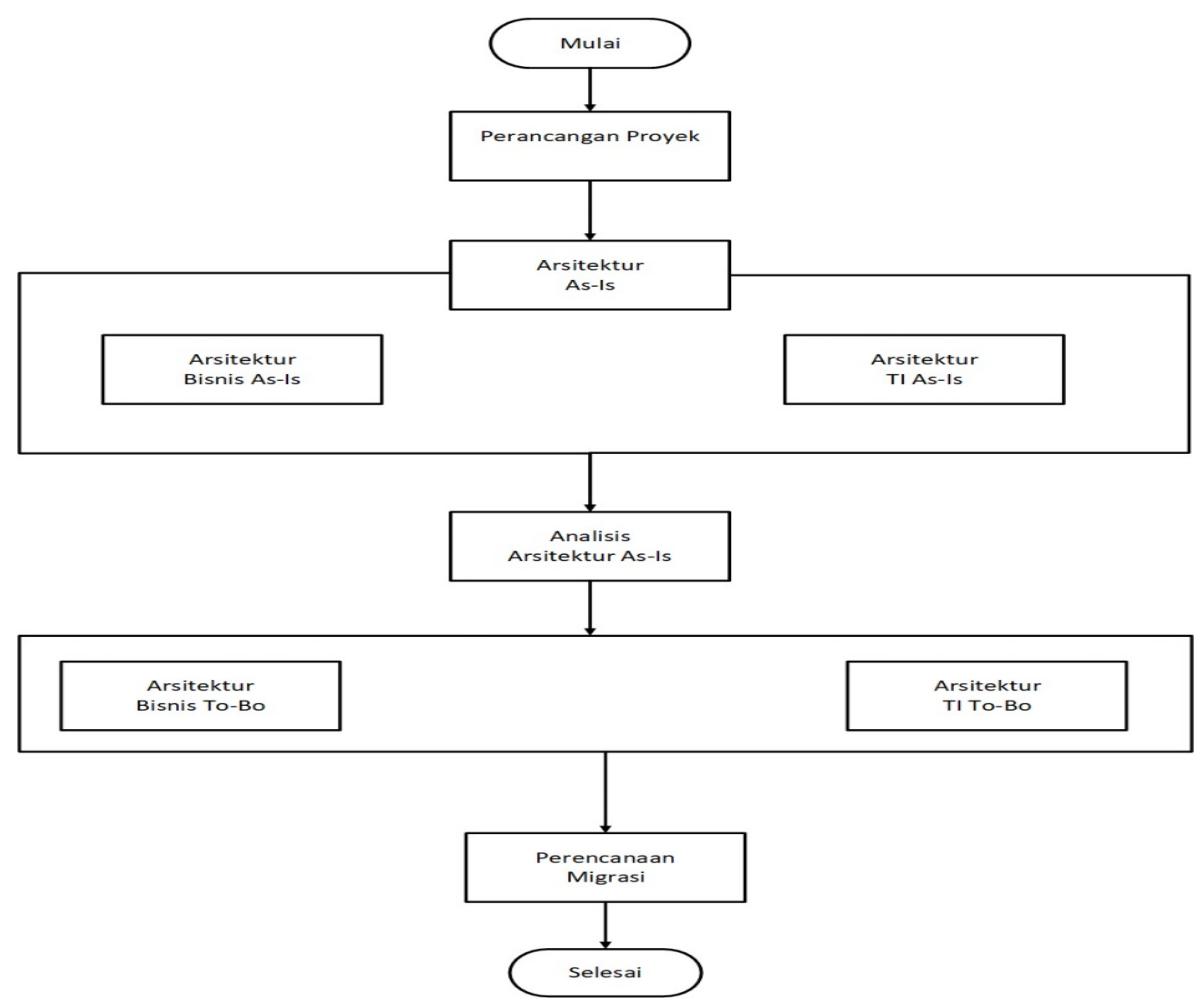

Gambar 4. Metodologi Penelitian

Gambar 4 menunjukkan alur metodologi penelitian ini. Pertama-tama dilakukan analisis terhadap arsitektur bisnis dan TI as-is untuk mendapatkan gap analysis yang selanjutnya akan dibuatkan perancangan arsitektur bisnis dan TI to-be. 


\subsection{Analisis Arsitektur Bisnis As-is}

Analisis fokus pada pengumpulan informasi pada posisi saat ini dari bidangbidang kegiatan penjualan tiket dan membuat gambaran yang jelas tentang gap capability yang bisa menjadi hambatan dalam mencapai potensi pendapatan secara keseluruhan.

Analisis arsitektur bisnis tiket memetakan gambaran awal tujuan, sasaran, dan capaian bisnis tiket PT Railink secara arsitektural. Untuk mengetahui arsitektur bisnis as-is tiket PT Railink, maka perlu mengetahui perkembangan penggunaan dari $e$ ticketing as-is di unit komersial di PT Railink. Arsitektur bisnis as-is diketahui berdasarkan dokumen blueprint yang dimiliki oleh PT Railink.

\subsection{Analisis Arsitektur TI As-Is}

Analisis arsitektur TI yang mencakup arsitektur TI dari sistem penjualan tiket saat ini di PT Railink, melakukan review terhadap infrastruktur teknologi informasi yang digunakan dan melakukan pengamatan peran sumber daya dan sistem informasi di dalam proses bisnis penjualan tiket.

\subsection{Perancangan Arsitektur Bisnis To-be}

Perancangan arsitektur bisnis to-be meliputi tiga service bisnis berikut:

1. Service bisnis core

Service bisnis core terkait dengan proses bisnis utama sistem tiket PT Railink dimulai dari transaksi reservasi (booking), pembayaran, gate-in dan gate-out serta pembatalan tiket.

2. Service bisnis non-core

Service bisnis non-core terkait dengan proses bisnis pendukung. Service bisnis noncore meliputi service tiket manual dan pengiriman e-mail.

3. Service eksternal

Service eksternal yang diharapkan terdiri dari service dashboard laporan eksekutif dan rekonsiliasi pendapatan tiket payment gateway. 


\subsection{Perancangan Arsitektur TI To-be}

Perancangan arsitektur TaI to-be akan meliputi service-service sebagai berikut:

1. Service Aplikasi

Service aplikasi dibangun berdasarkan service bisnisnya. Suatu service bisnis dapat memiliki satu atau lebih service aplikasi disertai dengan penamaan service dan alamat URL Service dapat diakses sesuai kesepakatan standar protokol komunikasi yang menjembatani aplikasi-aplikasi front-end dengan servicenya.

2. Service Infrastruktur

Service infrastruktur dirancang untuk mendukung service aplikasi baik digunakan secara fisik maupun menggunakan virtualisasi melalui sekumpulan sumber daya infrastruktur seperti server web, server aplikasi, server database, server lain, dan media penyimpanan (storage).

\section{HASIL DAN PEMBAHASAN}

\subsection{Analisis Arsitektur As-is}

Analisis kondisi arsitektur saat ini (as-is) dilakukan berdasarkan kondisi bisnis serta kondisi TI perusahaan. Analisis tersebut ditujukan terhadap informasi posisi saat ini dan dalam rangka membuat gambaran proses bisnis yang sedang berlangsung disertai gap capability yang menjadi hambatan di dalam perancangan sistem $e$-ticketing kereta api sebagai upaya perusahaan dalam hal ini PT Railink mendorong pendapatan dari bisnis transportasi angkutan penumpang kereta api.

\subsubsection{Analisis Arsitektur Bisnis As-is}

Dalam analisis arsitektur bisnis as-is, didapat dari hasil analisis struktur bisnis perusahaan dan relasinya dengan stakeholders. Analisis bisnis as-is memetakan gambaran awal tujuan, sasaran, dan capaian bisnis. 


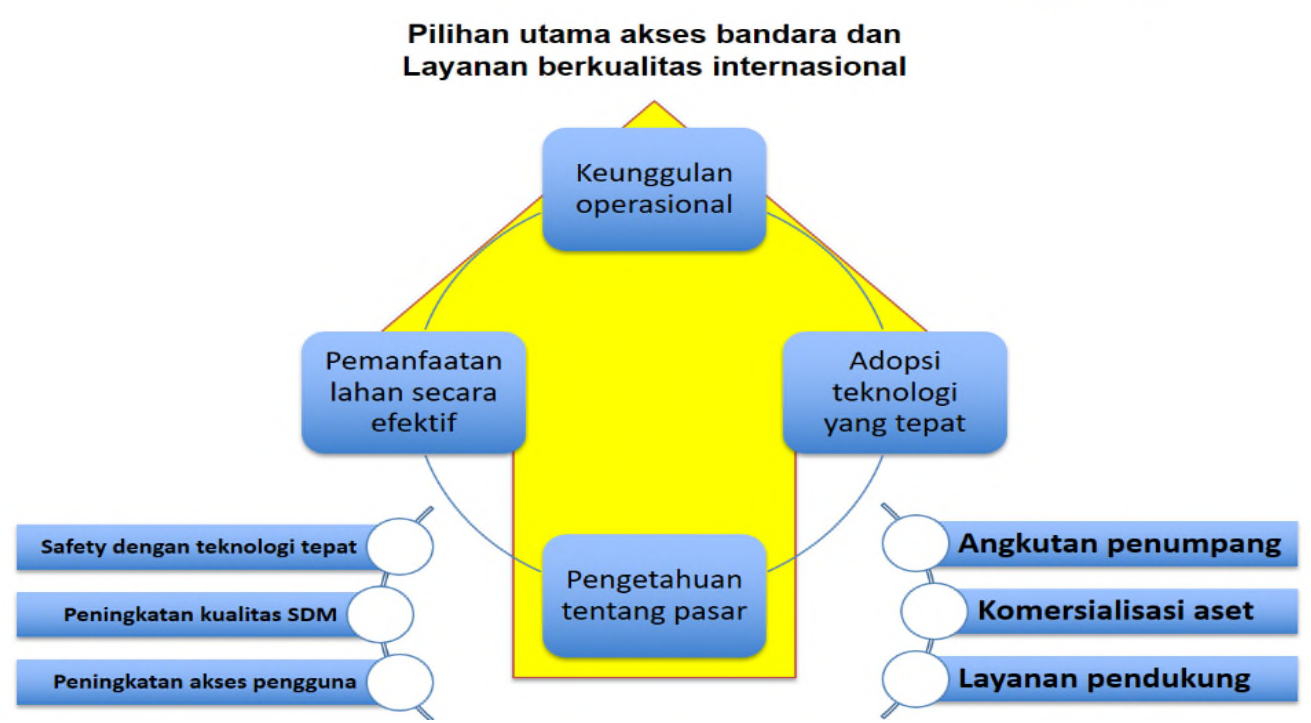

Gambar 5. Konteks Bisnis Perusahaan

Bisnis utama PT Railink terdiri dari usaha bisnis angkutan penumpang, komersialisasi aset, dan layanan pendukung bisnis lainnya. Faktor kunci keberhasilan untuk mencapai keunggulan operasional yaitu dengan upaya-upaya: penerapan safety dengan teknologi yang tepat, peningkatan kualitan SDM, dan peningkatan akses pengguna. Siklus dalam mencapai keunggulan operasional tersebut tidak terlepas dari kegiatan-kegiatan: pengetahuan tentang pasar, adopsi teknologi yang tepat, dan pemanfaatan lahan secara efektif. Sistem e-ticketing kereta api merupakan pilihan utama yang menunjang pendapatan perusahaan dalam bisnis angkutan penumpang.

\subsubsection{Service Bisnis As-is}

Diagram Use Case dari Service Bisnis As-is dapat digambarkan pada gambar 7 sebagai berikut: 


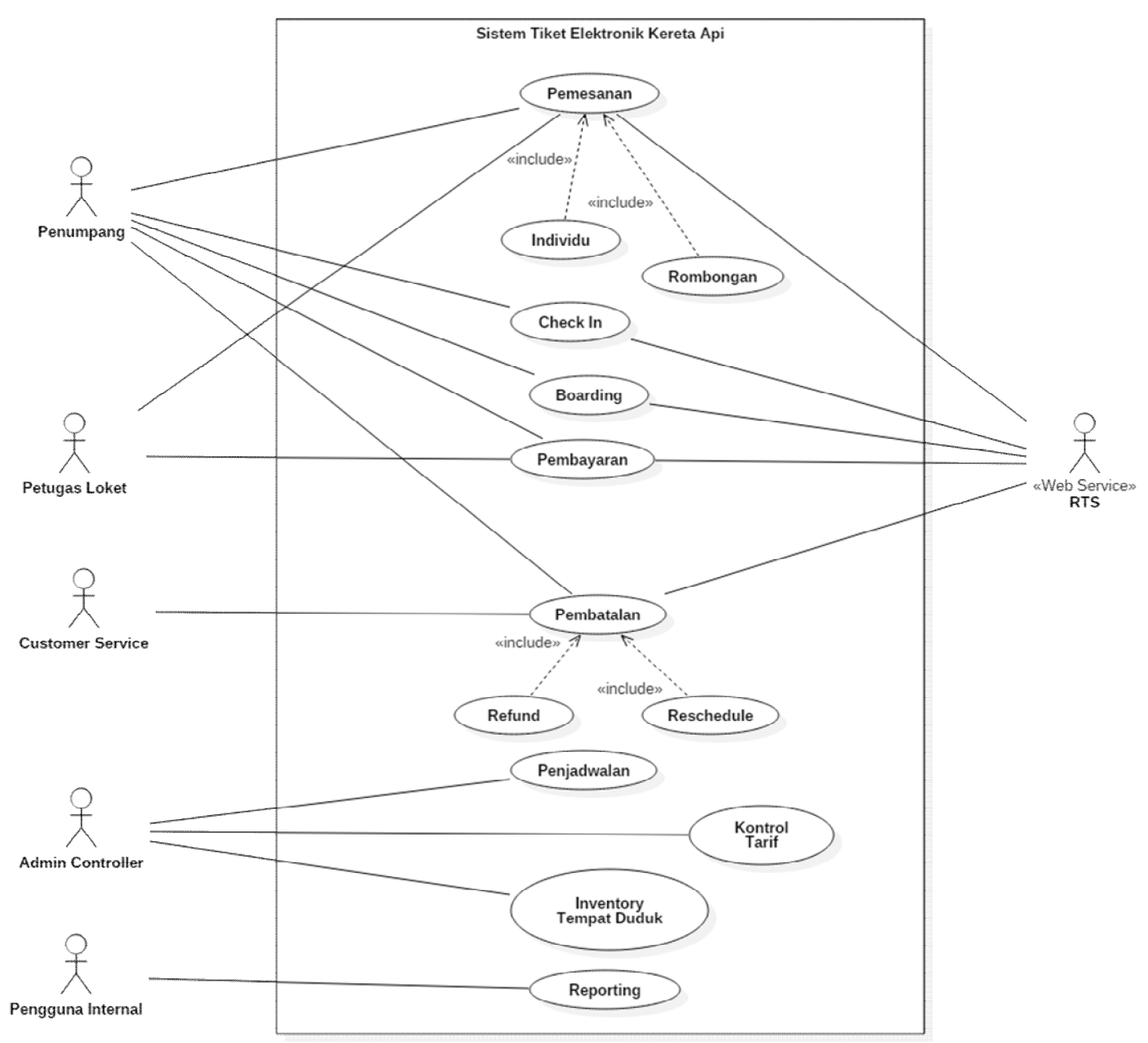

Gambar 6. Diagram use Case Proses Bisnis As-is

Proses bisnis as-is secara global untuk penjualan tiket seperti pada Gambar memiliki 3 (tiga) kelompok proses bisnis utama sebagai berikut:

a. Pemesanan dan Penjualan Tiket, serta Pembayaran untuk penumpang individu dan rombongan;

b. Pembatalan dan Pengembalian Bea (Refund)

c. Check In dan boarding untuk penumpang individu maupun rombongan;

Proses bisnis as-is untuk pengguna internal dan administrator memiliki 4 (empat) proses bisnis sebagai berikut:
a. Proses penjadwalan (scheduling)
b. Proses pentarifan
c. Pengendalian inventory tempat duduk
d. Pembuatan Laporan-laporan 


\subsubsection{Gap Analysis}

Dari hasil identifikasi terhadap proses bisnis as-is, maka didapat beberapa gap kebutuhan bisnis pada sistem yang akan diimplementasikan sebagaimana dijelaskan pada tabel 3 berikut:

Tabel 3. Identifikasi Gap Kebutuhan Proses Bisnis

\begin{tabular}{|c|c|c|c|c|}
\hline No. & Masalah & Kondisi $A s-i s$ & Kebutuhan TI & Gap \\
\hline 1 & $\begin{array}{l}\text { Pemesanan } \\
\text { dan } \\
\text { pembayaran } \\
\text { dilayani di } \\
\text { Loket }\end{array}$ & $\begin{array}{l}\text { Pemesanan dan } \\
\text { Pembayaran yang } \\
\text { dilakukan di } \\
\text { stasiun yang } \\
\text { masih dilayani di } \\
\text { loket }\end{array}$ & $\begin{array}{l}\text { Pelayanan pemesanan } \\
\text { dan pembayaran yang } \\
\text { cepat cukup dilakukan } \\
\text { melalui Vending } \\
\text { Machine. }\end{array}$ & $\begin{array}{l}\text { Waktu pelayanan } \\
\text { yang tidak cepat } \\
\text { menimbulkan } \\
\text { antrian calon } \\
\text { penumpang pada } \\
\text { jam-jam sibuk. } \\
\text { Peniadaan petugas } \\
\text { loket }\end{array}$ \\
\hline 2 & $\begin{array}{l}\text { Pembayaran } \\
\text { tunai pada } \\
\text { loket di } \\
\text { stasiun }\end{array}$ & $\begin{array}{l}\text { Pembayaran } \\
\text { menggunakan } \\
\text { uang tunai }\end{array}$ & $\begin{array}{l}\text { Pembayaran dilakukan } \\
\text { secara non-tunai untuk } \\
\text { mempercepat proses } \\
\text { transaksi pembayaran } \\
\text { dan minimal kesalahan } \\
\text { perhitungan manual } \\
\text { uang tunai. }\end{array}$ & $\begin{array}{l}\text { Mesin EDC } \\
\text { tunggal untuk } \\
\text { akomodasi } \\
\text { transaksi non-tunai } \\
\text { berbagai bank } \\
\text { nasional. }\end{array}$ \\
\hline 3 & $\begin{array}{l}\text { Proses Check- } \\
\text { in dan } \\
\text { Boarding }\end{array}$ & $\begin{array}{l}\text { Penumpang yang } \\
\text { sudah memiliki } \\
\text { tiket harus check- } \\
\text { in dan boarding }\end{array}$ & $\begin{array}{l}\text { Proses gate-in } \\
\text { dijadikan satu proses } \\
\text { baik check-in dan } \\
\text { boarding untuk } \\
\text { meringkas proses } \\
\text { antrian penumpang } \\
\text { masuk peron dan } \\
\text { penumpang tidak } \\
\text { menumpuk di stasiun. }\end{array}$ & $\begin{array}{l}\text { Proses gate-in dan } \\
\text { gate-out }\end{array}$ \\
\hline
\end{tabular}

\subsubsection{Analisis Arsitektur TI As-is}

Analisis arsitektur TI As-is terdiri dari Analisis Arsitektur TI dengan identifkasi sumber daya TI teknis dan non-teknis. Analisis arstiektur TI As-is mencakup analisis arsitektur dari sisi sistem informasi dan infrastruktur.

a. Perancangan Arsitektur To-be

Perancangan Arsitektur to-be dari sistem tiket elektronik kereta api pada PT Railink terdiri dari perancangan Arsitektur bisnis to-be dan perancangan Arsitektur TI to-be. 
b. Perancangan Arsitektur Bisnis To-be

Perancangan Arsitektur Bisnis to-be dapat dijelaskan pada diagram use case bisnis sebagai berikut:

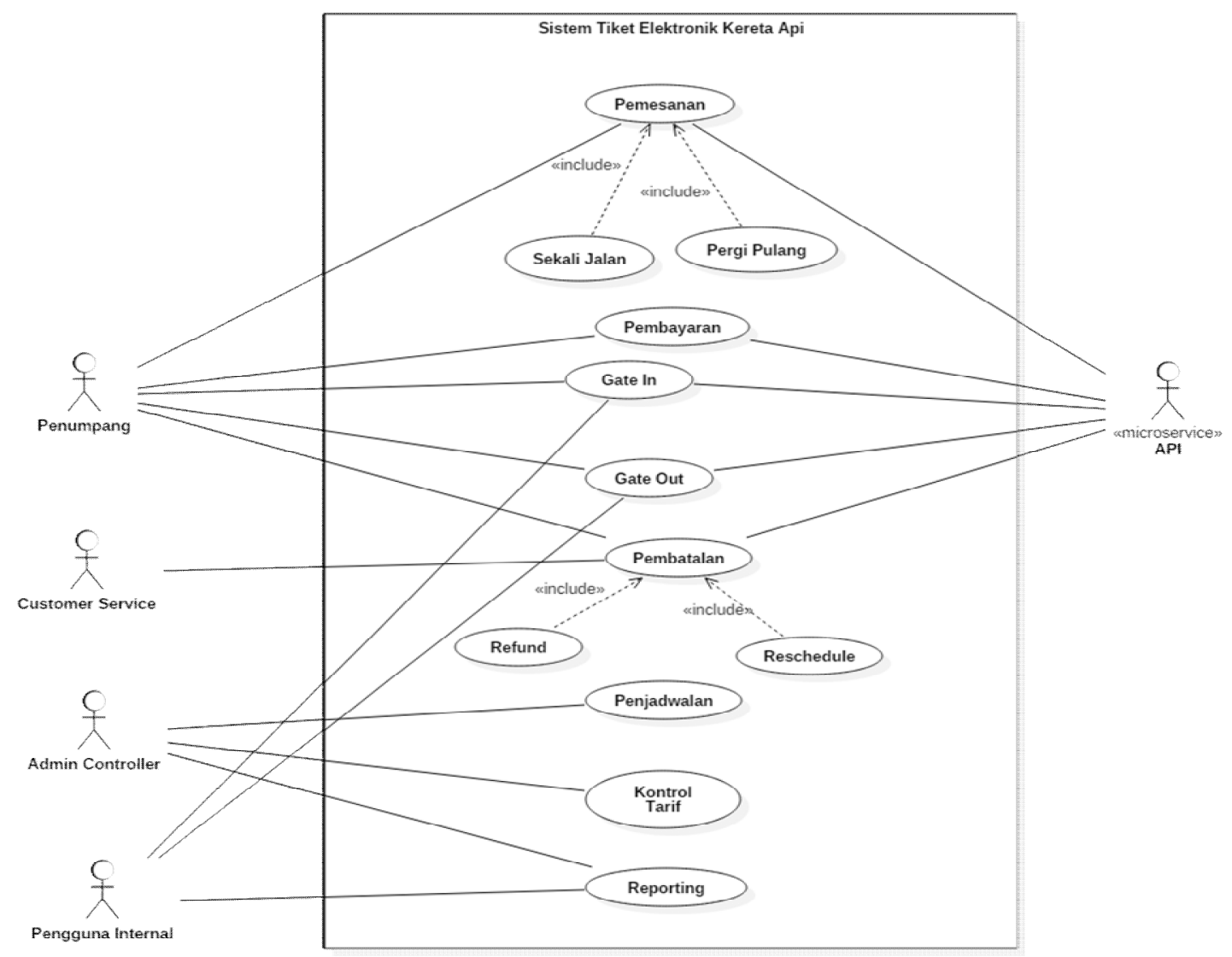

Gambar 7. Diagram Use Case Bisnis To-be

\subsubsection{Diagram Activity}

Dari fungsi-fungsi bisnis yang terdapat dalam Diagram Use Case To-be Sistem Eticketing Kereta Api, maka terdapat aliran aktivitas pada Diagram Activity sebagai berikut:

1. Diagram Activity Proses Pemesanan

2. Diagram Activity Proses Pembayaran

3. Diagram Activity Proses Gate-in

4. Diagram Activity Proses Gate-out

5. Diagram Activity Proses Pembatalan

6. Diagram Activity Proses Penjadwalan 
7. Diagram Activity Setting Tarif

8. Diagram Activity Web Reporting

\subsubsection{Service Bisnis To-be}

Berdasarkan definisi use case, kebutuhan service-service dikekompokkan ke dalam kategori service core, service non-core, dan service eksternal. Service core merupakan service utama atau penting dari sebuah service bisnis, dimana bisnis mengembangkan atau mengoperasikan aktivitas utamanya. Service non-core merupakan kumpulan dari service penunjang service core. Dan kelompok service eksternal kaitanya dengan kebutuhan tambahan dan hubungan service dengan lingkungan eksternal. Service core yang dikembangkan pada sistem e-ticketing kereta api to-be yaitu: Service Schedule, Service Transaction, Service Payment, dan Service Gate. Service non-core terdiri dari Service Info dan Service E-mail. Sedangkan service eksternal yaitu service payment-gateway.

\subsubsection{Perancangan Arsitektur TI To-be}

Sistem E-ticketing kereta api dikembangkan menggunakan Java Spring Boot, dengan arsitektur dapat dilihat pada Gambar 9 yang menggambarkan implementasi Arsitektur Microservice. Gambar 9 juga menunjukkan letak dari service-service yang berfungsi untuk menangani fungsi bisnis aplikasi, yaitu pada microservice node yang terbungkus oleh Zuul proxy sebagai gateway sistem load balancer, dengan Eureka server dan Config server untuk memungkinkan manajemen sistem yang terpusat dan dinamis. 


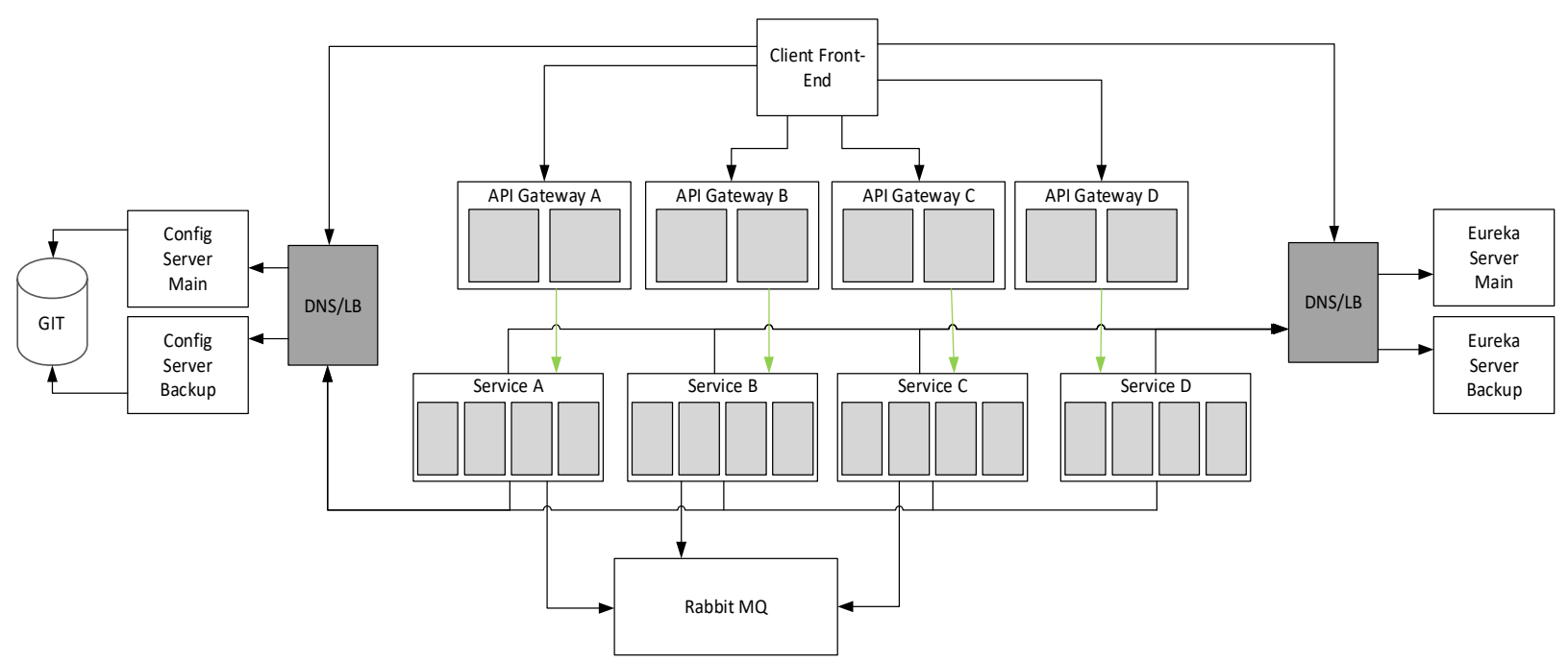

Gambar 8. Arsitektur Microservice Sistem E-ticketing Kereta Api

Keterangan :

1. Spring Cloud Config

Spring Cloud Config menyediakan dukungan server dan client-side untuk konfigurasi externalized dalam sistem terdistribusi. Dengan "Config Server" sistem ini memiliki tempat sentral untuk mengelola properti eksternal untuk aplikasi di semua lingkungan. Implementasi standar dari backend server penyimpanan menggunakan "git".

2. Server Eureka.

Server Eureka untuk Service registry: Sebuah registri service menyediakan lingkungan runtime untuk service untuk secara otomatis mempublikasikan ketersediaannya pada saat runtime. Sebuah registri akan menjadi sumber informasi yang baik untuk memahami topologi service di setiap titik.

3. Zuul Proxy

Zuul Proxy secara internal menggunakan server Eureka untuk service discovery, dan Ribbon untuk load balancing antara service. Proxy Zuul juga mampu melakukan routing, monitoring, mengelola ketahanan, keamanan, dan sebagainya. Secara sederhana, dapat dipertimbangkan untuk menggunakan Zuul service reverse proxy. Dengan Zuul, bahkan dapat diubah perilaku dasar dari service tersebut pada lapisan API. 


\subsubsection{Perancangan Arsitektur Infrastruktur To-be}

Blok diagram aliran secara global operasional darii Sistem E-ticketing Kereta Api to-be dapat diseperti pada gambar 9.

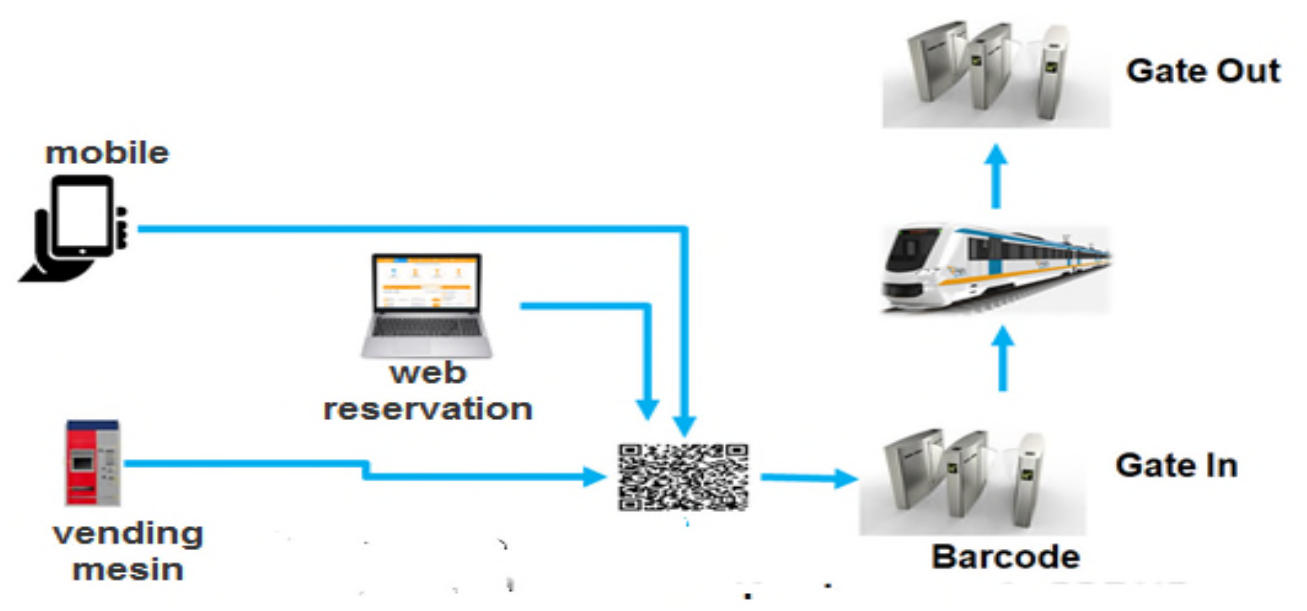

Gambar 9. Diagram aliran global operasional sistem e-ticketing kereta api to-be

Beberapa tahapan dalam mendapatkan tiket kereta api ada beberapa cara yaitu:

1. Pemesanan melalui aplikasi mobile

Customer dapat melakukan pemesanan melalui handphone dengan aplikasi yang berbasis android atau IOS dan langsung mendapatkan nomor tiket sesuai dengan tanggal pemesanan setelah melakukan pembayaran sehingga bisa memudahkan customer tanpa harus datang langsung ke stasiun. Pada saat customer sudah ke stasuin customer cukup menempelkan barcode pada mesin gate yang ada di stasiun pada saat pemberangkatan kereta maupun keluar dari stasiun kereta api

2. Pemesanan atau pembelian tiket langsung kereta api dilakukan dengan cara mendatangi langsung ke stasiun dan dilakukan melalui vending machine

3. Pemesanan melalui web reservasi, customer bisa langsung memesan melalui alamat web reservasi kereta api dan langsung membayar melalui e-commerce maupun transfer sehingga ketika datang ke stasiun cukup menunjukan barcode tiket yang sudah dibeli pada mesin gate kereta api.

\section{KESIMPULAN}

Perancangan Arsitektur bisnis sistem e-ticketing dimulai dengan melakukan analisis terhadap proses bisnis as-is dengan mendefiniskan fungsi-fungsi bisnis pada sistem e-ticketing yang sedang berjalan. Definisi fungsi-fungsi bisnis tersebut dianalisis 
gap yang menjadi kendala dalam pengembangan untuk menentukan perubahan fungsi bisnis dalam perancangan arsitektur bisnis to-be. Hasil gap analysis dari perancangan arsitektur bisnis tersebut adalah:

a. Sistem pembayaran tiket elektronik secara non-tunai.

b. Pelayanan penjualan tiket elektronik yang tidak menggunakan loket sebagai channel penjualannya.

c. Perbaikan proses pada proses validasi penumpang kereta api yang akan naik kereta api dengan melakukan proses gate-in dan gate-out.

Perancangan Arsitektur teknologi informasi sistem e-ticketing kereta api to-be berbasis service menerapkan perancangan Arsitektur aplikasi menggunakan kerangka Service Oriented Enterprise Architecture (SOEA) berbasis microservice dimana fungsi bisnis dari perancangan aristektur bisnis, masing-masing dijadikan sebagai serviceservice kecil yang independen, resilien, dan dapat berintegrasi dengan platform yang berbeda dengan standar protokol API. Arsitektur sistem e-ticketing kereta api didukung dengan topologi infrastruktur jaringan yang memiliki kapabilitas tinggi untuk memenuhi kebutuhan sistem e-ticketing yang dapat beroperasi selama 24 jam non-stop dan downtime server yang minimal.

\section{DAFTAR PUSTAKA}

Assauri, Sofyan., Manajemen Pemasaran Dasar, Konsep, dan Strategi. PT. Jakarta: Grafindopersada.2011

David, Fred. R. and Forest R., Strategic Management Concept and Cases 14th Edition. Pearson Education. New Jersey. USA. 2012.

Engels, G., Assman, M., Service-Oriented Enterprise Architectures: Evolution of Concepts and Methods. Department of Computer Science University of Paderborn. München, Germany. 2008.

Erl, Thomas, Service-Oriented Architecture: Concepts, Technology, and Design. Prentice Hall PTR. New Jersey. USA. 2005.

Haki, M. Kazem, Forte, M. Wentland. Service Oriented Enterprise Architecture Framework, University of Lausanne, Switzerland. 2010

Heydt-Benjamin, T.S., Chae, H., Defend, B., Fu, K,. Privacy for Public Transportation, University of Massachusetts, Amherst, MA. USA. 2006

Karami, Mitra. Factor Influencing Adopting Online Ticketing. Lu lea University of Technology. Swedia. 2006 